\title{
III. DEBIUTY
}

\author{
Grzegorz Bryl (Warszawa)
}

\section{Symbolika miecza \\ w polskich XVI-wiecznych kompendiach prawa miejskiego}

\begin{abstract}
WSTEPP
Pierwsza połowa XVI w. stanowi przełom w europejskich dziejach źródeł prawa, gdyż wprowadzenie i upowszechnienie druku umożliwiło ich standaryzację, nieosiągalną w okresie stosowania rękopisów ${ }^{1}$. Ten czynnik, a także przemiany kultury prawnej związane z renesansowymi wpływami romanistycznymi oraz dynamiką dziejów politycznych leżały u podstaw bogatej XVI-wiecznej twórczości prawniczej. W warunkach polskich mowa przede wszystkim o twórczości dotyczącej prawa miejskiego, kodyfikującego specyficzną miejscową wersję prawa

${ }^{1}$ S. Estreicher, Kultura prawnicza w Polsce XVI wieku, Kraków 1931, s. 1. Niemożność standaryzacji oznaczała dla kodyfikatorów czy kompilatorów konieczność wybierania pomiędzy różniącymi się, a równoprawnymi wersjami tego samego dzieła - o skutkach tej sytuacji dla prac Mikołaja Jaskiera: Z. Rymaszewski, Lacińskie teksty Landrechtu Zwierciadła Saskiego w Polsce. Jaskier - tekst główny i noty marginesowe, „Acta Universitatis Lodziensis. Folia Iuridica” 1985, nr 18, s. 213. Jak wskazuje M. Mikuła, dopiero wtedy sensu nabiera historiograficzna kategoria tekstu autentycznego, a groźba modyfikacji przy każdorazowym przepisywaniu zanika. Zob. M. Mikuła, Die Modifizierung des Erb- und Familienrechts im Magdeburger Weichbildrecht (Einführung zum Thema) [w:] D. Janicka (red.), Judiciary and Society between Privacy and Publicity. 8th Conference on Legal History in the Baltic Sea Area, Torun 2016 (w dalszej części tego tekstu przedstawiona jest analiza takich modyfikacji w obszarze prawa spadkowego); idem, Prawo miejskie magdeburskie (Ius municipale magdeburgense) w Polsce XIV - pocz. XVI w.: studium o ewolucji i adaptacji prawa, Kraków 2018, s. 19-22, 188-190.
\end{abstract}


magdeburskiego ${ }^{2}$, traktowaną już jako prawo polskie, a nie niemieckie ${ }^{3}$. Efektami tego ruchu intelektualnego były dzieła, które stały się tekstami ważnymi dla praktyki życia społecznego ${ }^{4}$ - m.in. z racji braku czynnika analogicznego do efektywnego oporu szlachty koronnej przeciw projektom kodyfikacji prawa. Podstawą ich opracowania były elementarne źródła obowiązującego w większości polskich miast prawa magdeburskiego - Weichbild magdeburski (Ius municipale magdeburgense) i Zwierciadto saskie (Sachsenspiegel).

Teksty te, w pierwotnej formie pochodzące z XII-XIV w. ${ }^{5}$, zawierały bogatą treść ideologiczną. Niniejszy artykuł stanowi próbę ujęcia problemu recepcji owych treści ideowych prawa magdeburskiego w XVI-wiecznych polskich kompendiach prawa miejskiego. Ze względu na praktyczną popularność tych kompendiów jest to zagadnienie ciekawe zarówno pod kątem mechanizmów recypowania, tłumaczenia i adaptowania tekstu prawnego, jak i ewentualnego kontaktu czytelnika z treściami ideologicznymi. Jako praca wstępna artykuł porusza problematykę jednego pojęcia nacechowanego ideowo, bardzo często pojawiającego się oraz przywołującego bogaty wachlarz treści - miecza.

W kulturze średniowiecznej miecz jako pojęcie abstrakcyjne w kontekstach ideowo-politycznych występował w związku ze swoją rolą atrybutu władcy oraz

${ }^{2}$ L. Pauli, Die polnische Literatur des Magdeburger Rechts im 16. Jahrhundert [w:] D. Willoweit, W. Schich (red.), Studien zur Geschichte des sächsisch-magdeburgischen Rechts in Deutschland und Polen, Frankfurt am Main - Bern - Las Vegas 1979, s. 151.

3 J. Bardach, Recepcja w historii państwa i prawa, „Czasopismo Prawno-Historyczne” 1977, t. XXIX, z. 1, s. 47.

${ }^{4}$ Przy czym w praktyce literatura prawnicza była traktowana na równi z tekstami normatywnymi o usankcjonowanym przez monarchę statusie. Zob. M. Mikołajczyk, Przestępstwo $i$ kara w prawie miast Polski południowej XVI-XVIII wieku, Katowice 1998, s. 14. O ich stosowaniu już w XVI w.: W. Maisel, Poznańskie prawo karne do końca XVI wieku, Poznań 1963, s. 17. Ustalenia na temat stosowania omawianych dzieł przynoszą liczne badania szczegółowe nad praktyką sądową; jeden z przykładów z małego miasta: Z. Głąb, Zbrodnia i kara - z dziejów przestępczości w małym mieście w XVII wieku (na przyktadzie Lutomierska), część II, „Studia z Dziejów Państwa i Prawa Polskiego" 208, t. XII, s. 101-105. Uwagi na temat szerokiego, również geograficznie, oddziaływania tej literatury: H. Lück, Aspects of the transfer of the Saxon-Magdeburg Law to Central and Eastern Europe, „Rechtsgeschichte - Legal History” 2014, nr 22, s. 84.

${ }^{5}$ Podstawowe informacje o tych tekstach: W. Carls, Rechtsquellen sächsisch-magdeburgischen Rechts im Untersuchungsgebiet Polen [w:] I. Bily, W. Carls, K. Gönczi, Sächsisch-magdeburgisches Recht in Polen: Untersuchungen zur Geschichte des Rechts und seiner Sprache, Berlin - Boston 2011, s. 71-87; K. Kamińska, Lokacje miast na prawie magdeburskim na ziemiach polskich do 1370 r. (studium historycznoprawne), Torun 1990, s. 55-62; czy informacje i wnioski H. Lücka, Woher kommt das Lehnrecht des Sachsenspiegels? [w:] K.-H. Spieß (red.), Vorträge und Forschungen: Ausbildung und Verbreitung des Lehnwesens im Reich und in Italien im 12. und 13. Jahrhundert, Konstanz 2013, s. 241-250, 267-268. Na temat ich powstania i relacji: J. Weitzel, Zum Rechtsbegriff der Magdeburger Schöffen [w:] D. Willoweit, W. Schich (red.), Studien zur Geschichte..., s. 65-71, 80-82; krytycznie wobec opinii o wtórności Weichbildu względem Zwierciadła: M. Mikuła, Prawo miejskie..., s. 177-178. 
narzędzia utrzymywania porządku i egzekucji prawa, jako symbol władzy, prawa i sprawiedliwości - mając $w$ różnych kontekstach bogatszą symbolikę 6 , także jako namacalny obiekt ${ }^{7}$. Przede wszystkim wywodzące się z germańskich wyobrażeń o władcy-wojowniku skojarzenie zostało w procesie chrystianizacji i sakralizacji władzy królewskiej wzbogacone i zmodyfikowane przez elementy chrześcijańskie. W związku z nową koncepcją pochodzenia i funkcji władzy symbolika miecza objęła zatem sfery związane szczególnie ze sprawiedliwością (w tym w sądzie ${ }^{8}$ ) i miłosierdziem oraz opieką (wobec słabych i ubogich) 9 .

$\mathrm{Na}$ gruncie niemieckim, w związku z cesarską ideologią niemieckich monarchów, istotne znaczenie miała koncepcja dwu mieczy symbolizujących władzę świecką i duchową. Wywodzi się ona z passusu listu papieża Gelasiusa do cesarza (wschodnio)rzymskiego Anastasiosa I. Pochodzący z tego listu motyw dwóch władz, świeckiej i duchowej, został wzbogacony o motyw miecza najpierw od strony świeckiej (miecz w kręgu germańskim był atrybutem władcy), a potem zaczął symbolizować obie władze, z odwołaniem do Ewangelii (Łk 22,38). Czasy otwartego konfliktu między cesarzem a papieżem („spór o inwestyturę”) utrwaliły tę symbolikę ${ }^{10}$.

Recepcja tej symboliki na ziemiach polskich w obszarze prawa nie jest dogłębnie zbadana - zagadnienie to pojawia się w pracy Olgierda Ławrynowicza ${ }^{11}$, ogólne rozważania archeologiczno-prawnych kompendiów Witolda Maisla uzupełnił zaś dla zabytków z Dolnego Śląska Maciej Trzciński ${ }^{12}$. Widoczne są związki

${ }^{6}$ Handwörterbuch zur deutschen Rechtsgeschichte, 31. Lieferung, Berlin 1989, s. 1570-1574.

${ }^{7}$ W. Maisel wskazuje na miecz katowski wraz z jego zdobieniami (Archeologia prawna Europy, Warszawa - Poznań 1989, s. 141-142), a przede wszystkim na miecze, którym przypisywano moc sprawczą w ramach rytuału: jako insygnium władców świeckich - funkcja koronacyjna i broń króla przeznaczona do obrony własnej i obrony Kościoła; na wyspie Man obecność miecza wymagana dla dokonywania pewnych czynności prawno-ustrojowych; a także miecze do pasowania, ceremonialne („ceremonijne”). Ibidem, s. 249-252.

${ }^{8}$ Źródłem inspiracji jest tu oczywiście Biblia - miecz w kontekście boskiego atrybutu sprawiedliwości pojawia się m.in. w: Ps 7,12-15; Ap 1,16.

${ }^{9}$ M. Rokosz, Polskie insygnia $w$ średniowiecznych fabułach [w:] J. Banaszkiewicz (red.), Imagines Potestatis: rytuaty, symbole i konteksty fabularne władzy zwierzchniej: Polska $X-X V$ w. (z przykładem czeskim i ruskim), Warszawa 1994, s. 213.

${ }_{10}$ I.S. Robinson, Church and papacy [w:] J.H. Burns (red.), The Cambridge History of Medieval Political Thought c. 350 - c. 1450, Cambridge - New York 1988, s. 288-305.

${ }^{11}$ Wskazuje on na motyw egzekucji prawa oraz ceremonialne przekazanie miecza, pierwotnie związane z uznaniem osiągnięcia dojrzałości, oraz na znaczenia związane z wymiarem sprawiedliwości leżącym w gestii władcy - widoczne już na monetach Bolesława Śmiałego. Zob. O. Ławrynowicz, Treści ideowe broni rycerskiej w Polsce wieków średnich, Łódź 2005, s. 85-88.

${ }_{12}$ M. Trzciński, Miecz katowski, pręeierz, szubienica: zabytki jurysdykcji karnej na Dolnym Śląsku (XIII-XVIII w.), Wrocław 2001. Trzciński wskazuje, że mieczowi przysługiwało najznamienitsze miejsce pośród wielu rodzajów broni zaczepnej (s. 33); był „synonimem stanu rycerskiego" ze względu na wysoką wartość wymienną i ograniczoną dostępność; miał być przedchrześcijańskim 
tego motywu z wpływami niemieckimi. Wobec tego godne uwagi wydaje się rozpatrzenie jego obecności w pozostającej w oczywistej zależności od zabytków prawa niemieckiego i kultury niemieckiej obfitej XVI-wiecznej polskiej twórczości prawniczej prawa miejskiego. Wiemy przy tym, że w miastach polskich prawo to oddalało się od niemieckich wzorców, m.in. wskutek wpływów miejscowej praktyki i prawa rzymskiego, przemian socjoekonomicznych czy realizacji wydanego przez Kazimierza Wielkiego zakazu zwracania się z zapytaniami do Magdeburga ${ }^{13}$.

\section{BAZA ŹRÓDŁOWA}

W artykule przedstawiam wyniki analizy czternastu różnorodnych tekstów pięciu autorów:

- Jana Jelonka Cervusa Tucholczyka (prawnika związanego z Akademią Krakowską) Farrago actionum juris Magdeburgensis (Cerv1) - kompendium prawa miejskiego z 1531 r. przeznaczone dla praktyków i uczących się, w tym wydaniu zdominowane jeszcze przez element sasko-magdeburski ${ }^{14}$. Stanowi ono pierwsze opracowanie prawa miejskiego w Polsce, wykorzystywane przez późniejszych autorów ${ }^{15}$. Praca ta odróżnia się od pozostałych analizowanych źródeł faktem powstania przed wydaniem w 1535 r. kompilacji translatorskiej Jaskiera. Dzieło Jaskiera jako usankcjonowane przez króla źródło prawa będzie ważną podstawą

źródłem symbolicznej mocy, władzy i prawa, a symbolikę tę dla świata chrześcijańskiego potwierdziła Biblia - płomienisty miecz archanioła był stróżem woli Bożej; broń ta mogła więc być postrzegana jako narzędzie Boże, monarszy atrybut używany przy ceremoniach koronacyjnych, a potem także symbol najwyższej władzy sądowniczej (formuła ius gladii) i narzędzie wykonywania kary śmierci, w praktyce życia prawnego pojawiając się jako miecz sędziowski i miecz katowski.

${ }^{13}$ K. Bukowska-Gorgoni, Das sächsisch-magdeburgische Recht und die vermögensrechtlichen Verhältnisse in den polnischen Städten der Renaissance [w:] D. Willoweit, W. Schich (red.), Studien zur Geschichte...; o poglądach XVI-wiecznych autorów na temat relacji praw: magdeburskiego, polskiego i rzymskiego I. Kwiatkowska, Die Stellung des sächsisch-magdeburgischen Rechts in der Normenhierarchie nach den Anschauungen polnischer Juristen des 16. uns 17. Jahrhunderts [w:] ibidem, s. 145-147. O uwarunkowaniach oddziaływań romanistycznych: K. Bukowska, O recepcji prawa rzymskiego w prawie miejskim $w$ dawnej Polsce, „Czasopismo Prawno-Historyczne” 1968, t. XX, z. 1, s. 78-82.

${ }^{14}$ L. Pauli, Die polnische Literatur..., s. 152.

${ }^{15}$ W. Bojarski, Z. Naworski, Jan Jelonek Cervus z Tucholi i jego twórczość prawnicza. Ustrój sądów i prawo procesowe, Toruń 1993, s. 9 (autorzy ci dokumentują również autorstwo Tucholczyka w odniesieniu do trzech pierwszych wydań, w których brak jego nazwiska - s. 38); L. Dargun wykazuje zależność Groickiego od Farrago: O źródłach prawa miast polskich w wieku szesnastym. II. O źródtach porządku sadowego spraw miejskich Prawa Magdeburskiego przez Barttomieja Groickiego, „Rozprawy i Sprawozdania z Posiedzeń Wydziału Historyczno-Filozoficznego Akademii Umiejętności" 1891, t. 25, s. 123-150. 
źródłową dla późniejszych autorów, podczas gdy Tucholczyk korzystał z tekstów wydanych w Commune incliti... Jana Łaskiego z 1506 r.;

- tego autora Farraginis actionum iuris civilis \& provincialis, Saxonici, Municipalisque Maydeburgensis: Libri septem: Per Ioannem Cervum Tucholiensem, collecti et revisi (Cerv2) - znacznie odmienna od wydania czwartego (1540) wersja powyższej pracy, cytująca kodyfikację justyniańską częściej niż źródła prawa niemieckiego i przybierająca formę traktatu o charakterze naukowym ${ }^{16}$;

- Mikolaja Jaskiera (aktywnego prawnika, pisarza miejskiego ${ }^{17}$ ) Juris provincialis quod Speculum Saxonum vulgo nuncupatus libri tres opera vigilanti in correctiorem redacti materiam, adjuncti simul glossis aliisque additionibus noviter reccollectis pro interpraelatione textus magis neccessariis Annotatainsuper in marginibus habentur loca legum Jurisque municipalis Magdeburg, materiam textus et glossarum approbantia declarantiaque grato lectori magnum afferentia commodum in Reg a Polonie (JSpec) - łaciński tekst Zwierciadta saskiego wraz z glosą oraz dodatkiem własnych glos marginesowych, wydany w Krakowie w 1535 r. ${ }^{18}$ i na mocy sankcji królewskiej Zygmunta Starego stanowiący źródło prawa miast posługujących się prawem magdeburskim, a w związku z tym również ważną podstawę dla prac późniejszych autorów ${ }^{19}$;

- tego autora Juris Municipalis Majdeburgensis Liber vulgo Weichbild nuncupatus ex vetustissimis exemplaribus vigilanti opera nuper latinitatis datus, summaque diligentia recognitus, adjunctis simul glossis et lextus interpretationibs ad id necessariis (JIM) - podobne do powyższego thumaczenie Weichbildu; stawiana była teza o współautorstwie dzieł Jaskiera z Janem Kirsteinem Cerasinusem, wówczas jego zastępcą na stanowisku pisarza ${ }^{20}$. Nie będę rozróżniał między glosą a tekstem głównym, jako że obie te części dzieł Jaskiera są pod względem treści tekstem recypowanym;

- Jana Kirsteina-Cerasinusa (początkowo związanego z Jaskierem, będącego w szczytowym momencie kariery wójta Sądu Wyższego Prawa Niemieckiego na

16 W. Bojarski, Z. Naworski, Jan Jelonek Cervus..., s. 37, 42-43; o powszechności romanizacji spisów prawa na ziemiach niemieckich w XVI w.: J. Bardach, Recepcja w historii..., s. 32-33; sprzyjała temu ideologia ciągłości cesarstwa.

${ }_{17}$ S. Pańków, Jaskier Mikołaj [w:] Polski Słownik Biograficzny, t. XI, Kraków 1965, s. 60-62.

18 Jak argumentuje Z. Rymaszewski (Lacińskie teksty..., s. 6-27, 33, 217-218), nie jest to autorskie tłumaczenie Jaskiera, ale kompilacja starannie wyselekcjonowanych fragmentów z istniejących wcześniej tłumaczeń łacińskich, mająca na celu usunięcie błędów oraz uzdatnienie tekstu do użytku praktycznego - wszak tłumaczenie było już dostępne w druku (tekst Łaskiego). Co do fragmentów autorstwa Jaskiera: ibidem, s. 184; część not została przetłumaczona z niemieckiego przez samego Jaskiera (s. 191), co także nie ma znaczenia dla sposobu traktowania tego tekstu.

${ }^{19}$ K. Bukowska-Gorgoni, Das sächsisch-magdeburgische Recht..., s. 131.

${ }^{20}$ L. Pauli, Jan Kirstein Cerasinus (1507-1561). Krakowski prawnik doby odrodzenia. Studium z dziejów praw obcych i literatury prawniczej w Polsce, Kraków 1971, s. 29. 
Zamku Krakowskim ${ }^{21}$ ) Enchiridion aliquot locorum communium iuris magdeburgensis (Cer) z 1556 r. - podręcznik objaśniający wybrane zagadnienia prawa magdeburskiego ${ }^{22}$, oparty na Zwierciadle i Weichbildzie wraz z glosami, a także kilku konstytucjach Karola V, Corpus Iuris Civilis i pracach Jaskiera ${ }^{23}$;

- Bartlomieja Groickiego ${ }^{24}$ (związanego z krakowskim sądem wyższym ${ }^{25}$ autora popularnych w praktyce sądowej prac traktowanych jako źródło prawa, wydawanych wielokrotnie aż do $1760 \mathrm{r}^{26}$ ) Artykuly prawa magdeburskiego, które zowiq Speculum Saxonum (Art) z 1558 r. - niesystematyczny zbiór przepisów oparty na łacińskich tłumaczeniach źródeł prawa magdeburskiego wydanych przez Jaskiera, z pewnymi uzupełnieniami autorskimi opartymi na praktyce sądów i uzupełniony kilkoma statutami dotyczącymi sądownictwa miejskiego odnoszącymi się do sytuacji szlachty i organizacji policji ogniowej;

- tego autora Ustawa placej u sądów w prawie majdeburskim (Pta) z 1558 r., przekład statutu rady krakowskiej z 1547 r.;

- tego autora Ten postępek wybran jest z praw cesarskich, który Karolus $V$ cesarz kazat wydac po wszystkich swoich państwiech etc. $\left(\boldsymbol{P o s t}^{27}\right)$ z 1559 r., praca oparta na tzw. Constitutione criminali Carolina, acz niebędąca systematycznym thumaczeniem;

- tego autora Porzadek sądów i spraw miejskich prawa majdeburskiego (Porz) z 1559 r., stanowiący zestawienie przepisów prawa procesowego;

- tego autora Rejestr do Porzqdku i do Artykułów prawa majdeburskiego i cesarskiego $(\boldsymbol{R} \boldsymbol{e j})$ z 1567 r., zawierający także uzupełnienia przepisów, formularze prawne i słownik synonimów ułatwiający korzystanie z rejestru;

- tego autora Tytuly prawa majdeburskiego do Porządku i do Artykutów, pierwej po polsku wydanych, w sprawach tego czasu najwięcej kłopotnych z tegoż prawa majdeburskiego przydane (Tyt) z 1567 r. - uzupełnienie na potrzeby praktyki, oparte na Zwierciadle, Weichbildzie, wilkierzach krakowskich, pracach Cervusa Tucholczyka i Cerasinusa, drzewie genealogicznym przygotowanym przez Stani-

${ }^{21}$ W. Ogrodziński, Cerasinus (Kyrstein) Jan [w:] Polski Słownik Biograficzny, t. III, Kraków 1937, s. 230-231.

${ }^{22}$ Ibidem, s. 25 - ,zwięzły podręcznik dla młodzieży”.

${ }^{23}$ Ibidem, s. 32-39.

${ }^{24}$ Do dzieł prawniczych Groickiego zalicza się, poza analizowanymi tu pracami, także wydane w 1547 r. w Krakowie Abrogatio et moderatio abusuum et sumptuum; tekst ten nie zawiera użyć słowa gladius, ponadto ma niewielką objętość i strukturalnie różni się od pozostałych źródeł, co przemawia za wyłączeniem go z bazy źródłowej.

${ }^{25}$ K. Koranyi, M. Patkaniowski, Groicki (Grodzicki) Barttomiej [w:] Polski Stownik Biograficzny, t. VIII, Kraków 1960, s. 628-629.

${ }^{26}$ G.M. Kowalski, Barttomiej Groicki - prawnik polskiego Odrodzenia [w:] Bartłomiej Groicki. Prawnik polskiego Odrodzenia. Wystawa w 400-setna rocznicę śmierci, Kraków 2005, s. 13.

${ }^{27}$ Praca znana jako Postępek sądów około karania na gardle. 
sława Eichlera, a także pracach Jana de Ferrarisa, Jodoka Damhoudera i źródłach romanistycznych ${ }^{28}$, bogate w ocenne komentarze odautorskie;

- tego autora Obrona sierot $\boldsymbol{i}$ wdów (Obr), wydana pośmiertnie w 1605 r., oparta na pracy Jodoka Damhoudera Pupillorum patrocinium, legum et praxeos studiosis non minus utile quam necessarium, wzbogacona o odniesienia do Zwierciadła i Weichbildu, informacje o przepisach prawa ziemskiego i przykłady z podręcznika Cerasinusa;

- Pawła Szczerbica, aktywnego w życiu Lwowa pisarza miejskiego i właściciela drukarni, nobilitowanego w 1585 r. dworzanina królewskiego ${ }^{29}$, Ius Municipale (SzIM), wydane we Lwowie w 1581 r. - thumaczenie na polski Weichbildu (w przeciwieństwie do silnie przetworzonych i będących komentarzami prac Groickiego ${ }^{30}$ );

- tego autora Speculum Saxonum (SzSS) z 1581 r., thumaczenie - czerpiące jednak także z Weichbildu - w układzie haseł alfabetycznych, mające ułatwić stosowanie prawa i uprzystępnić je nieprofesjonalistom ${ }^{31}$ - ale także z odsyłaczami do artykułów Zwierciadła, z których zaczerpnięto dane przepisy. Szczerbic w swoich thumaczeniach uwzględniał częściowo glosę.

W przypadku dzieł Jaskiera i Szczerbica ${ }^{32}$ będziemy mieć zatem do czynienia z thumaczeniami tekstów prawa magdeburskiego, Artykuty, Postępek... i Porzadek sądów są tłumaczeniami znacznie zmodyfikowanymi ${ }^{33}$, zaś pozostałe to dzieła już bardziej niezależne od tych podstawowych przekazów źródłowych ${ }^{34}$. Zidentyfikowane w tych różnych źródłach użycia słowa „miecz”/gladius, przyporządkowane do różnych znaczeń o różnej intensywności sensu symbolicznego, zostaną w tej pracy poddane próbie typologii. Następnie dokonane zostanie porównanie analizowanych

${ }^{28} \mathrm{O}$ źródłach romanistycznych u Groickiego: M. Patkaniowski, Na marginesie nowego wydania dziet Bartlomieja Groickiego, „Państwo i Prawo” 1956, t. 11, z. 1, s. 146-147.

${ }^{29}$ G.M. Kowalski, Szczerbic Pawet h. Jelita [w:] Polski Stownik Biograficzny, t. XLVII, Kraków 2011, s. 397-401.

${ }^{30}$ G.M. Kowalski, Wstep [w:] Ius municipale, to jest prawo miejskie magdeburskie..., wyd. i oprac. G.M. Kowalski, Kraków 2011, s. XI; S. Kutrzeba, Historja źródet dawnego prawa polskiego, Kraków 1987, s. 214: „tekstu trzymał się wiernie, choć nie miał nieraz znaczenia dla polskich stosunków".

${ }^{31}$ G.M. Kowalski, Wstęp [w:] Speculum Saxonum albo prawo saskie..., t. 1, wyd. i oprac. G.M. Kowalski, Kraków 2016, s. X.

${ }^{32}$ Szczerbic w dedykacji i przedmowie do Speculi Saxoni podkreśla, że starał się thumaczyć jak najdokładniej. O metodzie pracy Szczerbica, z wnioskami potwierdzającymi tę wypowiedź: M. Mikuła, Prawo miejskie..., s. 189.

${ }^{33}$ Jak wskazuje G.M. Kowalski (Bartłomiej Groicki..., s. 14-15), Groicki świadomie ingerował nawet w dyspozycje norm, m.in. zmniejszając okrucieństwo kar. S. Estreicher (Kultura prawnicza..., s. 35-36) podkreśla, że modyfikacje wprowadzane w tej literaturze musiały zastąpić reformę prawa.

${ }^{34}$ Podobną klasyfikację przedstawia Pauli, Die polnische Literatur..., s. 156. O samodzielności Tucholczyka i Kirsteina-Cerasina: S. Estreicher, Kultura prawnicza..., s. 22. 
tekstów pod kątem obecności tejże symboliki, mające na względzie naturę tych prac i stopień ich zależności od średniowiecznych tekstów niemieckich.

\section{TYPOLOGIA ZNACZEŃ JĘZYKOWYCH}

\subsection{Znaczenie dosłowne}

Najmniej istotne dla tego wywodu są wypadki, w których słowo miecz/gladius pojawia się w tekstach źródłowych jako oznaczenie przedmiotu, bez wyraźnego przypisania dodatkowego sensu. Miecz pojawia się z konieczności w taki sposób w związku z przepisami o hergewecie (części spadku przeznaczonej wyłącznie dla męskich krewnych) u wszystkich autorów i niemal we wszystkich tekstach. Występuje jako narzędzie zbrodni - w thumaczeniach Szczerbica ${ }^{35}$ - oraz u Groickiego jako dowód popełnienia przestępstwa ${ }^{36}$; obecne są także przepisy dotyczące noszenia przy sobie miecza ${ }^{37}$ oraz uwagi na temat jego kradzieży ${ }^{38} \mathrm{i}$ zastosowania jako rekwizytu służącego do mierzenia, wreszcie - wspominany jest miecz stosowany w pojedynku sądowym, któremu także nie zostało wyraźnie nadane znaczenie ideowe $^{39}$. Nad tymi zastosowaniami słowa nie będą prowadzone dalsze rozważania.

\subsection{Język i obyczajowość}

Kolejną grupą, jak się wydaje o sporym znaczeniu kulturowym, są zastosowania związane ze zwrotami językowymi i zakorzenionymi w świadomości skojarzeniami, w niektórych przypadkach mogące mieć powiązania z obyczajowością.

Jako związane z ówczesnymi męskimi funkcjami społecznymi słowo to do dziś jest stosowane do oznaczania pokrewieństwa agnatycznego (krewni po mieczu/ex parte gladii $)^{40}$. W thumaczeniu Szczerbica i u Jaskiera oraz w podręczniku Kirsteina stosowane jest określenie pełnoletności (zdolności do czynności prawnych) jako zdolności do noszenia miecza ${ }^{41}$, pojawiają się także opisy mających służyć jej udowodnieniu czynności - właściwych dla rycerzy i dla mieszczan ${ }^{42}$. Ceremonia

${ }^{35}$ Np. SzIM, s. 229 i 252; SzSS s. 264 i 323-324.

36 „Najbliższy i najpewniejszy znak jest, gdy tako mówią: [...] ten miał miecz goły w ręku” Porz, s. 193.

${ }^{37}$ Np. JSpec, s. 309, 312 i 321; SZIM, s. 192.

${ }^{38}$ Np. SzSS, s. 50.

${ }^{39}$ Np. SZIM, s. 159.

${ }^{40}$ Np. Cerv1, s. 102; Cerv2, s. 393 i 512-513; Obr, s. 5 i 226; JSpec, s. 33, 46, 106, 201 i 352; $J I M$, s. 73; SzSS, s. 33, 47 i 48; SzIM, s. 131; i wiele innych.

${ }^{41}$ Cer, s. 58; JSpec, s. 120, 121, 516 i 518; SzSS, s. 174, 499, 522 i 523.

${ }^{42}$ Np. SzSS, s. 522-523: ,jeśli est tak mocny ze z kamienia [...] przypasawszy miecz i tarcz na sobie zawiesiwszy na koń bez pomocy wsiedzie” - o rycerzu; ,przypasawszy miecz sam bez pomocy przyidzie sądu a miecza dobędzie" - o mieszczaninie. 
przekazania miecza, niepowiązana w konieczny sposób z kwestią fizycznej siły recypienta, jako obrzęd związany z przejściem w dojrzałość znana jest w Europie z kultury rycerskiej i w ramach rodów panujących ${ }^{43}$.

Przepisy dotyczące uśmiercenia (zabójstwa, obrony koniecznej bądź kary śmierci ${ }^{44}$ ) często zawierają słowo „miecz”. Wydaje się, że nie dotyczą one wyłącznie czynów dokonanych z użyciem tego narzędzia - także w wypadkach, gdy nie jest to bezpośrednio podkreślone (przemawia za tym m.in. fakt, że ścięcie mieczem nie było jedyną formą kary śmierci, jaką prawo przewidywało dla morderców - a mimo to kara śmierci była określana jako kara miecza). Słowo „miecz” występuje tu zatem w użyciu metaforycznym bądź frazeologicznym ${ }^{45}$. Być może podobnie jest w innych wypadkach, w których miecz występuje jako narzędzie zadania śmierci bądź ran; pełne wyliczenie nie jest tu jednak potrzebne.

Wyłącznie w tłumaczeniach tekstów prawnych natknąłem się na porównanie funkcji obrony w wojnie i w procesie sądowym ${ }^{46}$. Umiejętności rzecznika procesowego w tej analogii występują jako narzędzie walki paralelne wobec miecza, co być może ma na celu wywyższenie tych profesjonalistów.

\subsection{Symbol pojęć abstrakcyjnych/atrybut}

W związku z ostatecznie niemiecką genezą omawianych tekstów bezpośrednio symboliczne znaczenia miecza w tych wypadkach, w których mamy do czynienia z bardziej systematycznym wykładem ideowym, organizowane są wokół teorii politycznej dwu mieczy, żywej na obszarze podlegającym zwierzchnictwu cesarskiemu. Wykład tej teorii pojawia się zwłaszcza w partiach początkowych tekstów; oryginalnie znajdował się w początkowych artykułach Zwierciadła i Weichbildu. Przykładowo Jan Cervus Tucholczyk zamieszcza następujące objaśnienie:

Vocanturque illi gladii potestates seu iudicia. Quemadmodum enim gladio soeculari arcentur puniuntur malefactores et ecessiui homines. Ita spirituali gladio arcentur animae excessiuae. Et si Apostolicus corrigere non possit gladio spirituali, Imperator eundem iuvare tenetur gladio soeculari, \& econtra, ita que unus alteri pro defensa Ecclesii Christiane auxilio esse debet ${ }^{47}$.

${ }^{43}$ O. Ławrynowicz, Treści ideowe..., s. 62-63, 76-77, 84-86.

${ }^{44}$ Np. SzSS s. 58: „Bo iako mieczem świeckim bywaio złoczyńce karani”, s. 256: „Aczkolwiek Meżoboyce mieczem maio być karani”; JSpec, s. 194: „homicidae vero gladio puniri”.

${ }^{45}$ Podobne wnioski można wysnuć z badań D. Wojtuckiego (Publiczne miejsca straceń na Dolnym Ślasku od XV do połowy XIX wieku, Katowice 2009, s. 129), na uogólnione skojarzenia ze słowem „miecz” wskazują również obserwacje T. Grabarczyka (Na gardle karanie. Kara śmierci w średniowiecznej Polsce, Warszawa 2008, s. 59, 68, 74).

46 JSpec, s. 246, 247 i 352; JIM, s. 91; SzIM, s. 92 i 177.

${ }^{47}$ Podobnie: SzSS, s. 58: „Dwu mieczów władza, to jest duchowno y swiecko ku obronie ludu swego Pan Christus w Kosciele swoim utwierdzil z ktorych iż papież ma Duchowno a rzymski Ce- 
Jedną z funkcji cesarskich przywoływanych przy okazji tych wywodów jest obrona wdów i sierot ${ }^{48}$. Jako symbol opieki miecz odrywa się od teorii politycznej - występuje w tej roli samodzielnie, niezależnie od wykładu ideowego legitymizującego władzę cesarską. Jest tak zwłaszcza przy wywodach uzasadniających normę, wedle której miecz jest częścią hergewetu, a w wypadku większej liczby synów dziedziczy go najstarszy z nich - co ma się wiązać z przyjęciem obowiązków wobec rodziny; motyw ten jest obecny w thumaczeniach podstawowych źródeł prawa miejskiego oraz śladowo w Obronie... ${ }^{49}$.

Funkcja atrybutu cesarskiego jest bezpośrednio wskazywana przy rozważaniach na temat wykonania kary śmierci na cesarzu, które wobec tej okoliczności powinno nastąpić przy użyciu innego narzędzia - złotego topora. Rozważania takie pojawiają się wyłącznie w przekładach ${ }^{50}$; tylko tam pojawia się też odwołanie do miecza w kontekście urzędników, których władza pochodzi z delegacji królewskiej, co zostało sformułowane poprzez metaforę przekazanego im miecza ${ }^{51}$. U Groickiego miecz występuje jako atrybut sędziego ${ }^{52}$; istnienie mieczy sędziowskich, o bogatej ornamentyce, potwierdza śląska kwerenda Trzcińskiego, który wskazuje także na ich obecność w ikonografii oraz rolę insygnium przy ogłaszaniu wyroku ${ }^{53}$. W powiązaniu z tą funkcją symboliczną miecz oznacza też możliwość przymuszania do posłuszeństwa ${ }^{54}$. Nie chodzi tu przy tym wyłącznie o władzę doczesną - istnieje bowiem również motyw miecza boskiej sprawiedliwości, który ma grozić niewłaściwie wypełniającym swe funkcje sędziom; motyw ten został przywołany w modelowej przysiędze z Tytułów Groickiego ${ }^{55}$ i z thumaczenia Szczerbica.

Miecz był też, jako narzędzie wykonywania kary śmierci, symbolem sądownictwa wyższego (rozumianego jako właściwe w sprawach, w których kara śmierci groziła) - co wyrażało się w pojęciu ius gladii, oznaczającym uprawnienie

sarz swiecko; a te miecze so władze y Sody dwojakie Duchowne y świeckie. Bo iako mieczem swieckim bywaio zloczynce karani tak też duchownym mieczem dusze grzeszne bywaio uymowane".

${ }^{48} \mathrm{~Np}$. SzSS, s. 59: „Do czego y to przystepuie że Cesarzowi dan iest miecz dla obrony prawa sprawiedliwości wdow y sierot który i w sadzie wszelakie rzeczy może czego papieżowi niedozwolono".

${ }^{49}$ Np. SzSS, s. $184 ;$ SZIM, s. 135; Obr, s. 5.

${ }^{50}$ SzIM, s. 57;

${ }^{51} J I M$, s. 106: ,nomine etiam regis in proposito intellegi debet potestas quelibet a rege constituta, quibus commissa administratio et gladius est iusticiam defendendi, in iusticiam vero debilitandi”.

${ }^{52}$ Post, s. 140: „i ma sędzia przedniejszy abo wójt drugim rozkazać zasieść i sam też ma na miejscu swoim sieść, wziąwszy w rękę laskę albo miecz dobyty, według zwyczaju każdej ziemie”; motyw znany z Caroliny.

${ }_{53}$ M. Trzciński, Miecz katowski..., s. 35, 39, 42, 45.

54 SzIM, s. 46.

${ }^{55} T y t$, s. 173: ,a niechaj będzie nade mną miecz abo sąd świecki, który na fałeszne sedzie jest postawiony etc." 
do sprawowania takich sądów przysługujące np. miastu ${ }^{56}$. W badanych tekstach odniesienie do tego zagadnienia napotkałem tylko raz - w Zwierciadle Jaskiera: „nulli enim licet interficere quemquam, nisi habeat gladii potestatem”57.

\section{PORÓWNANIE KOMPENDIÓW}

W uwzględniających glosę przekładach Jaskiera i Szczerbica występuje najbogatsza symbolika zarówno pod względem ilościowym (liczba przypadków posłużenia się nią oraz liczba znaczeń i kontekstów), jak i jakościowym (zwłaszcza że tylko tam mamy do czynienia z eksplicytnym wyrażaniem złożonych konstrukcji ideowych). Pozostałe teksty zachowują odwołania do ideowych treści miecza w dużo mniejszym stopniu. Jan Cervus Tucholczyk w rozbudowanej wersji Farrago zamieszcza cytowane wyżej objaśnienie zagadnienia dwu mieczy; poza tym pojawiają się u niego tylko użycia należące do pierwszej, uznanej za nieistotną, grupy oraz w oznaczeniach pokrewieństwa i pełnoletności. Podobnie jest w wypadku podręcznika Cerasinusa. U Groickiego w Artykułach z pojęciem tym mamy do czynienia tylko w kontekście hergewetu i choć wiąże on go z opieką nad sierotami (,kto bierze hergiewet, to jest zbroję, bliższy, któremu się dostanie miecz, to jest starszy między bracią, ten jako opiekun powinien w sądzie bronić sieroty tej, którą się opieka" ${ }^{58}$ ), to odwraca tę relację - w oryginalnych tekstach to przyjęcie miecza jest przedstawione jako wtórne wobec obowiązku opieki.

Ustawa płacej u sądów w ogóle nie wzbogaca tego materiału, czego można było się spodziewać ze względu na jej tematykę. W Porządku występują tylko znaczenia dosłowne, wyrażenie ,zgwałcenie pokoju pospolitego bądź ręką, mieczem, ogniem i którymkolwiek innym obyczajem", motyw karania mieczem i krótka wzmianka o teorii politycznej. Postępek... zawiera wzmiankę o mieczu i lasce sędziowskiej (jednak jest ona bardzo podobna do tej z Caroliny, wobec czego traktowanie jej jako informacji o praktyce w miastach polskich byłoby wątpliwe) oraz wzmiankę o karaniu mieczem - ale jako jeden z typów kary śmierci, a nie jej określenie ogólne. W Tytułach natykamy się tylko na miecz jako przedmiot materialny oraz miecz sprawiedliwości Bożej, podobnie w Obronie - przedmiot materialny, w jednym tylko miejscu powiązany z obowiązkiem opieki: „ktokolwiek jakich dóbr spadek bierze [...], bywa winien na jakie brzemię abo jaką powinność odprawić względem

${ }^{56}$ Trzciński przypuszcza, że na Śląsku mogły istnieć nawet specjalne miecze „miejskie” wyrażające symbolicznie posiadanie tego uprawnienia (Miecz katowski..., s. 50). Znane jest wykorzystanie tej symboliki w uroczystościach (D. Wojtucki, Kat i jego warsztat pracy na Ślasku, Górnych Łużycach i hrabstwie kłodzkim, Warszawa 2014, s. 361-363).

57 JSpec, s. 310.

${ }^{58}$ Art, s. 135. 
dóbr, które bierze. [...] a kto hergwet, jako jest krewny po ojcu, któremu opieka należy, a mianowicie starszemu synowi miedzy krewnemi, ten sierot bronić winien i na znak tego bierze miecz ${ }^{59}$ ".

Tak znikome wykorzystanie motywu miecza w dziele poświęconym sytuacji wdów i sierot, a także nikła obecność w tych tekstach, które nie są przede wszystkim thumaczeniami, frazy o karaniu mieczem jako ogólnego określenia kary śmierci niezależnie od sposobu jej wykonania - wydają się jeszcze bardziej znamienne niż nieobecność wstępów ideologiczno-historycznych, które jako obszerne partie tekstu zbędne w dziełach nakierowanych na praktykę musiały być pomijane przez omawianych autorów.

\section{PRÓBA OBJAŚNIENIA MECHANIZMÓW RECEPCJI}

Groicki wskazuje, że „w Koronie Polskiej wszystkie miasta, wsi i szlachta mają to uprzywilejowanie, że mogą sądzić na gardło złoczyńcę"60. Oczywiście nie oznacza to, że każde miasto miało własnego kata - byłoby to zbyt kosztowne ${ }^{61}$. Jednak utrzymywanie kata nie było jak widać szczególnym przywilejem wyróżnionych miast $^{62}$. I chociaż przechowywanie miecza na ratuszu nie było pozbawione zna-

59 Obr, s. 229.

60 Post, s. 102.

61 T. Grabarczyk, Na gardle karanie..., s. 54-55; o wysokich kosztach utrzymania nawet w wypadku wypożyczania kata z innego miasta - wraz z zacytowanymi w całości rejestrami wydatków: J. Szymański, Biecki kat w Wojniczu [w:] J. Chrobaczyński, A. Jureczko, M. Śliwa (red.), Ojczyzna bliższa i dalsza. Studia historyczne ofiarowane Feliksowi Kirykowi w sześćdziesiąta rocznicę urodzin, Kraków 1993, s. 180-183.

62 Mało rozbudowane rozważania J. Koredczuka na temat iuris gladii (Ius gladii [w:] P. Jurek (red.), W kręgu dziejów wymiaru sprawiedliwości. Materiaty III Konferencji historyków państwa i prawa, Karłów 7-9 września 1999, Wrocław 2000) w zakresie miast odnoszą się głównie do wyróżniającego część miast przywileju karania za niektóre przestępstwa bez względu na stan i pochodzenie (s. 18), tzn. na uprawnienie odmienne od samego karania śmiercią i bardziej marginalne. Poza tym autor ów był zmuszony skupić się na materiale śląskim, i to w związku z reformami XVIII-wiecznymi; w kontekście polskim zwraca zaś uwagę na istotny czynnik otoczenia społecznego w postaci niezależności i arbitralności sądownictwa dominialnego - uprawnienie do karania śmiercią nie było niczym niezwykłym. Należy to mieć na uwadze, interpretując wyniki badań Z. Kulejewskiej-Topolskiej (Oznaczenia i klasyfikacje miast w dawnej Polsce, XVI-XVIII w., „Czasopismo Prawno-Historyczne” 1956, t. VIII, z. 2), która kategorię miast dysponujących prawem miecza odnajduje tylko w jednym źródle (s. 265), co znamienne, powstałym w 1784 r., po modyfikacji wspomnianego otoczenia społecznego, tj. po nałożeniu na panów ograniczeń w zakresie karania chłopów śmiercią. Analiza owego tekstu (T. Ostrowski, Prawo cywilne, albo szczególne, narodu polskiego ze statutów i konstytucji koronnych i litewskich zebrane, rezolucjami Rady Nieustającej objaśnione, dodatkami z praw kanonicznego, magdeburskiego i chetmińskiego pomnożone i porządkiem praw rzymskich ułożone, t. 1, 1784, s. 30) wskazuje skądinąd na marginalny i prawniczo-postulatywny charakter napomknięcia o „Prawie Miecza”, które zresztą w istocie nie stanowi 
czenia symbolicznego związanego z prawem miejskim jako takim, to nie istniały podstawy, by ius gladii stało się symbolem miejskiej suwerenności i niezależności ${ }^{63}$.

Z północy i centrum obszaru Rzeszy Niemieckiej znane jest zjawisko Rolandów ${ }^{64}$; Witold Maisel wskazuje, że owe figury rycerzy trzymających miecz (mające być znakami pozycji prawnej miast, wystawiających je w pobliżu siedzib swych władz) zastępują tam popularne w Europie „kolumny jurysdykcyjne” - symbole wolności miejskiej i uprawnień miasta w sferze prawnej ${ }^{65}$. Jacek Banaszkiewicz dopatruje się zaś obecności podobnych do kolumn wielozadaniowych obiektów-centrów życia wspólnotowego także w źródłach starożytnych oraz na pogańskim Połabiu i Pomorzu czy na terenach państwa Polan, odwołując się też do wymienianych przez Maisla konstrukcji zachodnioeuropejskich ${ }^{66}$. Można zatem mniemać, że właściwe dla jednego obszaru zastosowanie w tej powszechnie znanej funkcji postaci trzymającej miecz świadczy o partykularnym, regionalnym przypisywaniu owemu narzędziu szczególnej roli symbolicznej, a zarazem pewnie wzmacnia takie myślenie o mieczu. Brak Rolandów można więc chyba powiązać ze słabością poszukiwanej recepcji - w kontekście różnic w ustroju i ideologii władzy: miasta niemieckie dla podkreślenia niezależności mogły się odwoływać do symboliki cesarskiej, w Polsce była ona obca. Istotna jest także różnica w strukturze politycznej Polski i Niemiec - cesarz-monarcha w warunkach niemieckich był gwarantem wolności i przeciwwagą dla podlegających mu władców terytorialnych - bezpośrednich konkurentów miast; w polskiej strukturze władzy monarszej nie było miejsca na taki czynnik ${ }^{67}$, a miasta nie miały samodzielnej pozy-

tam kryterium wyróżniającego kategorię w ramach klasyfikacji miast. Skoro zaś, jak pisze $\mathrm{H}$. Zaremska (Niegodne rzemiosto. Kat w społeczeństwie Polski XIV-XVI w., Warszawa 1986, s. 15-20), sądy stanu panującego wypożyczały kata od miast, nie starając się pozyskać własnego, to kwestia prestiżu wynikającego z posiadania kata wydaje się ambiwalentna.

${ }^{63}$ Sporów o prawo karania śmiercią nie odnotowuje np. J. Bieniarzówna w studium Proces ograniczania autonomii miast małopolskich w pierwszej połowie XVI w., „Małopolskie Studia Historyczne" 1963, t. VI, z. 1/2.

${ }^{64}$ Próba objaśnienia ich znaczenia prawnego: B. Schwineköper, Zur Deutung der magdeburger Reitersäule [w:] P. Classen, P. Scheibert (red.), Festschrift Percy Ernst Schramm: zu seinem 70. Geburtstag von Schülern und Freunden zugeeignet, t. 1, Wiesbaden 1964, s. 117-142; por. H. Lück, Gerichtsstätten und Gerichtssymbolik [w:] G. Köster, Ch. Link (red.), Faszination Stadt. Die Urbanisierung Europas in Mittelalter und das Magdeburger Recht, Magdeburg 2019, s. 339.

${ }^{65}$ W. Maisel, Archeologia prawna Europy, s. 307-310; o perronach, krzyżach wolności, rollosach i innych tego rodzaju symbolach, obecnych na terenach Półwyspu Iberyjskiego i Apenińskiego oraz dzisiejszej Francji, Beneluksu i Nadrenii: ibidem, s. 297-307.

${ }^{66}$ J. Banaszkiewicz, Pons mercati, gradus lignei, stepen i inne. Uwagi o znaku władzy i prawa słowiańskich miejsc wiecowych [w:] Discernere vera ac falsa. Prace ofiarowane Józefowi Szymańskiemu w sześćdziesiąta rocznicę urodzin, Lublin 1990, s. 79-89.

${ }^{67}$ Król, jak podsumowuje Z. Rymaszewski, był w Polsce w stosunku do miast królewskich właścicielem, źródłem prawa, rozjemcą sporów czy gwarantem wewnętrznego ładu politycznego, 
$\mathrm{cji}^{68}$. Podstawowe dla legitymizacji stosowania prawa niemieckiego w miastach polskich problemy były odmienne niż w warunkach niemieckich i dotyczyły zwłaszcza sporu o to, czy jest ono ,prawem powszechnym miast polskich”, czy też jego obowiązywanie wymaga istnienia specjalnego przywileju dla danego miasta ${ }^{69}$. Skądinąd Magdeburg, jako miasto ottońskie ${ }^{70}$, był w czasie kształtowania się ideowych treści tekstów prawa magdeburskiego miastem, w którym ideologia cesarska oddziaływała szczególnie silnie, nawet jak na warunki niemieckie.

Kolejny trop zdaje się obecny w Najstarszym zwodzie prawa polskiego, gdzie spotykamy się z uwagą, że na praktykę gajenia sądów wśród ludności polskiej wpływ ma to, że ,ich władza sądowa nie wypływa na świat od cesarza, jak niemieckich książąt i sędziów"71. Takie rozumienie prawa wyłącza znów rolę ideologii władzy cesarskiej już na wczesnym etapie ${ }^{72}$ (w okresie późniejszym brak znaczenia legitymacji cesarskiej jest już oczywisty), tymczasem Weichbild wywodzi powiązanie miecza z wymiarem sprawiedliwości właśnie z motywu miecza władzy świeckiej, przekazanego sędziom przez jego dysponenta - cesarza.

a także zewnętrzną wobec środowiska miejskiego instancją apelacji czy wykładni, wreszcie (przynajmniej w specyficznym przypadku gdańskim) konkurentem, a nie partnerem i sojusznikiem w ramach skomplikowanej gry politycznej, jak cesarz w warunkach niemieckich. Zob. Z. Rymaszewski, Król w dawnej Polsce w świetle dokumentów praktyki sądowej, „Studia z Dziejów Państwa i Prawa Polskiego" 2002, t. VII, s. 174-175, 177.

${ }^{68}$ Podstawowe informacje na temat współczesnego standaryzacji źródeł prawa miejskiego procesu eliminowania elementów autonomicznego statusu, a zatem i warunków możliwości zakorzenienia ideologii niezależności: J. Bieniarzówna, Proces ograniczania autonomii... O ile badaczka wskazuje, że proces ten nie był jednokierunkowy, a jego wyniki nie były jeszcze jednoznaczne, o tyle przedstawiany przez nią materiał wskazuje na gospodarczy charakter stawek zachodzących konfliktów (np. spory o dochody z kar sądowych, handel chlebem, opłaty za słody, dostęp do lasu czy budowę wodociągów; ostatecznie toczą się one ze szlachcicami, zwłaszcza ze szlacheckimi wójtami czy starostami, a nie z władcami terytorialnymi), wynikający z tego nieraz „cywilnoprawny”, a nie ustrojowy charakter ewentualnych odwołań do argumentacji prawnej, czy też na to, że w niektórych wypadkach miasta walczyły głównie o sprawy prestiżowe związane z zachowaniem symbolicznych pozostałości autonomii - choć ingerencje królewskie w te spory były częste i nieraz dla miast korzystne. Zob. M. Bogucka, H. Samsonowicz, Dzieje miast i mieszczaństwa w Polsce przedrozbiorowej, Kraków 1986, s. 324-325.

${ }^{69}$ Komentarz na ten temat: M. Mikołajczyk, Proces kryminalny w miastach Małopolski XVIXVIII wieku, Katowice 2013, s. 565-566.

${ }^{70}$ M. Puhle, Magdeburg - średniowieczna metropolia i kolebka prawa magdeburskiego [w:] Europejskie miasta prawa magdeburskiego. Tradycja, dziedzictwo, identyfikacja, Kraków 2007, s. 12-16; H. Lück, Prawo magdeburskie jako czynnik identyfikacji europejskiej rodziny miast [w:] ibidem, s. 42-44.

${ }^{71}$ Najstarszy zwód prawa polskiego, wyd. J. Matuszewski, Warszawa 1959, punkt 2.1: ,ir gericht von dem keyser in dy welt icht erkunt, als dutscher vursten unde richter tut".

${ }^{72} \mathrm{O}$ przesuwaniu rozważań teoretycznych na koniec tekstu (w rękopisach tzw. układu śląskomagdeburskiego): M. Mikuła, Prawo miejskie..., s. 35 i cytowana tam literatura. 
W tych warunkach pozostaje mieczowi, poza funkcją symbolu monarszego, głównie rola narzędzia katowskiego oraz elementu niewiele już w miastach znaczącego $^{73}$ hergewetu - zdaje się więc, że brakuje podłoża, na którym recepcja jego symbolicznego znaczenia mogłaby się oprzeć. Trzy wskazane czynniki negatywne, wzajemnie ze sobą powiązane, funkcjonowały przez cały okres obowiązywania w polskich miastach tekstów prawa magdeburskiego - pozbawiając wyrażanych w tych tekstach ideologicznych treści związanych z symbolem miecza oparcia w wyobrażeniach i praktykach politycznych oraz w codziennie doświadczanej przestrzeni miejskiej.

Na podstawie zaprezentowanych cząstkowych badań źródłowych oraz rozważań nad nimi można sformułować wniosek, że prawo skodyfikowane w ustandaryzowanych źródłach proweniencji magdeburskiej służyło regulacji stosunków społecznych, ale już nie określaniu pozycji miasta w szerszej strukturze społecznej czy dostarczaniu ideowych podstaw funkcjonowania sądownictwa, a tym bardziej funkcjonowania społeczności miejskiej jako wspólnoty politycznej.

\section{THE SYMBOLISM OF THE SWORD \\ IN THE $16^{\text {TH }}$ CENTURY POLISH MUNICIPAL LAW COMPENDIUMS}

\section{Abstract}

Printed legal works based on the Magdeburg Law began to appear in Polish towns in the $16^{\text {th }}$ century. The article analyzes them in terms of the presence of references to the symbol of the sword which was significant in this law. The use of the word "sword/gladius" in the works of Cervus-Tucholczyk, Jaskier, Cerasinus, Groicki and Szczerbic was typologized according to the intensity of their symbolic sense ("literal meaning," "language and customs," "a symbol of abstract concepts"). Cases belonging to particular categories were analyzed. Their presence in individual texts was also examined, which led to the conclusion that the intensity (qualitative and quantitative) of these references depends on the degree of closeness of a given text to Sachsenspiegel and Weichbild as well as on the presence of a gloss in a given text. It leads to a conclusion that there was a negligible reception in Polish towns to the ideas contained within the contents of the German law. There are three proposals to explain this phenomenon. The first one refers to a lack of distinction between towns with and without ius gladii in Poland. The second proposal concerns the differences between the political structures in Poland and in German-speaking territories. The last one is connected with the deeply-rooted symbol of the sword in German lands, which was expressed and reinforced by the existence of Roland statues. The symbolism of the sword

${ }^{73}$ Szerzej na temat tej obiegowej już w historii prawa tezy, wraz z analizą reakcji literatury prawniczej i ustawodawstwa miejskiego (sięgających wstecz do XIV w.) na przemiany ról społecznych oraz na proporcjonalne obniżenie wartości hergewetu: P. Suski, Spory wokót gerady i hergewetu w polskim miejskim prawie spadkowym $w$ XVI w. [w:] M. Mikuła (red.), Prawo blisko człowieka. Z dziejów prawa rodzinnego i spadkowego, Kraków 2008, s. 170-175. 
in Poland was devoid of support in the urban space and in political perceptions. A thesis was also put forwarded which stated that the Magdeburg Law was not used to define the position of Polish towns in a wider structure nor to provide an ideological basis for their functioning as political communities.

Keyw ords: Magdeburg Law, sword, Groicki, Jaskier, Szczerbic 